\title{
Learner Sexual Offenders: Cyber Child Pornography
}

\author{
Prof S.A. Coetzee \\ Department of Educational Leadership and Management, University of South Africa \\ E-mail: coetzsa@unisa.ac.za
}

\section{Doi:10.5901/mjss.2013.v4n11p752}

\begin{abstract}
Much has been written about child pornography with the emphasis on children as the victims, but far less has been written on children as the manufacturers and distributors of cyber pornography and the role of the school in this regard. Thinking of children as sexual offenders is disturbing and even more so if one considers that the manufacturing and distributing of the pornography takes place at schools or during school activities. Learners filming sexual acts by co-learners, learners distributing videos of co-learners having sex; learners receiving or being in possession of messages containing pornographic images; sexting; accessing pornographic websites while at school; watching pornographic material on their cell phones on school grounds are increasingly becoming 'normal' behaviour for learners. Many of these actions constitute child pornography. Schools are faced with the dilemma of having to give recognition to learners' right to freedom of expression and privacy and promote the use of technology, but simultaneously fulfil their obligations to protect learners from exposure to pornographic material, educating learners on responsible use of the internet and cell phones, and disciplining learners who commit sexual misconduct by means of cyber technology.
\end{abstract}

\section{Introduction}

A survey conducted, under the auspices of the South African Films and Publication Board, in randomly-selected schools in Cape Town, Durban and Johannesburg among 934 learners between 13 and 17 years old, brought to light that 60\% is aware of friends distributing website addresses of pornographic sites to one another and $81 \%$ is aware of friends having pornographic images on their cell phones (Chetty \& Basson, 2006, p. 31-32). In September 2012 the Internet Watch Forum's analysts investigated how many instances of self-generated, sexually explicit online images and videos of young people were on the internet and found a total of 12,224 such images and videos, $88 \%$ of which were uploaded from the original websites to parasite websites (Internet Watch Foundation, 2012, p. 19). Owens, Behun, Manning and Reid (2012, p. 101, 116) contend that internet pornography is a global trend and that there is a need for research on "emerging trends towards technology use (in) production and distribution of one's own pornography (e.g. sexting, pornography, YouTube videos etc.)". A literature review brought to light that much research has already been done on sexting. There is, however, a lack of research on other forms of cyber sexual misconduct and I attempt to make a contribution to fill that gap with this paper.

Learners are increasingly producing and distributing child pornography, seemingly without realising the dangers. Hope (2006, p. 308), with reference to Feredi (1997), argues that online dangers (such as cyber child pornography) have brought new dimensions to schools as "risk environments". Learners are not only at risk but are also creating the risk because they are creating danger to themselves and others online (Hope, 2006, p. 313).

How can schools manage these new forms of cyber sexual misconduct and still observe learners' rights to privacy and freedom of speech? Schools are faced with the dilemma of having to observe learners' rights and promote the use of technology, but simultaneously fulfil their obligations to protect learners from exposure to pornographic material, educating learners on responsible use of the internet and cell phones, and disciplining learners who commit cyber sexual misconduct.

\section{Definition of "cyber child pornography"}

Cyber is a prefix for "forming words relating to electronic communication networks and virtual reality" (Reader's Digest 1998). This is the meaning attached to "cyber-" in this paper. Various authors such as Ahn, Bivona and DiScala (2011, p.1) and Owens et al. (2012, p. 102) refer to the ubiquitous nature of the internet. Internet access can be gained not only through computers but also through mobile technology, video game consoles or other electronic devices (Owens et al. 
2012, p. 104). Avenues that learners use to access, create or distribute child pornography include websites, blogs, discussion forums, chat rooms, instant MMS messaging or text messages and social network sites such as Facebook, Mxit, Twitter, MySpace, and Linkedln. "Cyber" in the term "cyber child pornography" refers to child pornography produced, distributed or accessed through the internet.

Although this paper is based on the argument that learners' conduct constitutes criminal behaviour, it is essential to remember there is a difference between "cyber child pornography" as a crime and as a form of sexual misconduct. Cyber child pornography as a crime and as a form of sexual misconduct is independent yet interrelated because one transgression can constitute both misconduct and a crime. Schools will be responsible to deal with cyber child pornography as a form of misconduct and the police with cyber child pornography as a crime.

The leading treaty regarding cybercrime (such as child pornography) is the Council of Europe's Convention on Cybercrime adopted in November 2001 (Council of Europe, 2001). The Convention was opened to worldwide membership and non-member States can thus ratify it (Keyser, 2003, p. 297). Article 9 of the Convention (Council of Europe, 2001) deals with child pornography and prohibits the following:

a. producing child pornography for the purpose of its distribution through a computer system;

b. offering or making available child pornography through a computer system;

c. distributing or transmitting child pornography through a computer system;

d. procuring child pornography through a computer system for oneself or for another person;

e. possessing child pornography in a computer system or on a computer-data storage medium.

For the purposes of this paper "through a computer system" is extended to include all technological avenues through which pornography can be produced, offered, distributed or procured in cyber space.

But what will constitute "child pornography"? The definition in article 20(2) of the Lanzarote Convention on the Protection of Children against sexual exploitation and abuse is used for the purposes of this paper: "'child pornography' shall mean any material that visually depicts a child engaged in real or simulated sexually explicit conduct or any depiction of a child's sexual organs for primary sexual purposes". If one takes the examples of learner sexual misconduct described in the literature and benchmark those against the above definition, the following conduct could be interpreted as constituting producing, making available, procuring, possessing or distributing cyber child pornography:

\subsection{Producing cyber child pornography}

- Learners filming sexual acts by co-learners (Campbell, 2008).

- Learners taking pictures of co-learners in the locker room while they are showering or toileting (Butler, Kift, \& Campbell, 2009, p. 94-95).

\subsection{Offering or making cyber child pornography available}

- Learners sending pornographic images that they have downloaded via Bluetooth to their friends at R5 each (Campbell, 2008).

- Learners sending co-learners or friends inappropriate images such as pictures of genitals or sex videos (Schrock, \& Boyd, 2011, p. 29).

- Learners trading with sexual images sexted to them (Wastler, 2010, p. 689).

\subsection{Procuring cyber child pornography}

To constitute procuring (downloading), the images do not need to be saved to the computer's hard drive or to a removable disk (Wortley, \& Smallbone, 2006).

- Learners downloading pornographic images (Schrock \& Boyd, 2011, p. 4)

- Accessing pornographic websites while at school (Campbell, 2008; Dowell, Burgess, \& Cavanaugh, 2009, p. 549-550).

\subsection{Possessing cyber child pornography}

Whitear-Nel (2011, p. 9) states that possession, in terms of the South African Films and Publication Act, includes keeping or storing in or on a computer, computer system or computer data storage medium. Inadvertent "possession" of child pornography would not constitute criminal possession since fault in the form of intention is required (Whitear-Nel, 2011, 
p. 9) However, if one accidentally stumbles across child pornography or receives unsolicited child pornography, without knowledge or suspicion of its source or origin, one should immediately delete the images or descriptions. The time lapse between the opening of the message containing child pornography and its deletion could be interpreted as possession (Film and Publication Board, par 7.3).

- Learners receiving or being in possession of messages containing pornographic images. The learner receiving a sexted image and opening it, is guilty of possessing child pornography.

\subsection{Distributing cyber child pornography}

Distribution will include the uploading and dissemination of pornographic images (Wortley \& Smallbone, 2006). Displaying unsolicited child pornography to another person, except a police officer, would amount to the offence of distribution (Film and Publication Board, par 7.2.2). Re-mailing a "spam" message or e-mail containing child pornography would also constitute distribution (Film and Publication Board, par 7.2.3).

- Learners distributing videos of co-learners having sex (Mukhuthu, 2011).

- Posting fake, obscene photographs on social networking websites (Brett, 2009).

- A learner taking pictures of her breasts and sending it to her boyfriend, a learner sending a picture of his genitals to his classmates, a boy forwarding a picture of his ex-girlfriend's breasts that she had sent him to his friend (Chetty, 2009, par 1; Crofts \& Lee, 2013, p. 85-86; Dowell et al., 2009, p. 551; Lenhart, 2009, p. 6; Schrock \& Boyd, 2011, p. 34; Theodore, 2010-11, pp. 370, 375). Sexting, a combination of "sex" and "texting", is a form of self-produced child pornography (Duncan, 2010, p. 1). It is defined by the CJCP, as the act of "sending nude or semi-nude photos or videos, including sexually suggestive messages through mobile phone texting or instant messaging." Theodore (2010-11, p. 367) maintains that it is only sexting if the picture is sent by a minor to a minor and not when a minor sends a sexually explicit picture to an adult. "Sexting" revealing photos of oneself, in the case of any person under the age of 18 years, is, in fact, the creation, possession and distribution of child pornography" (Chetty, 2009, par 2.1).

- Sending malicious text messages of a sexual nature (Hinduja \& Patchin, 2009; Lenhart, 2009, p. 7).

- Learners sexually harassing or bullying co-learners online, include "outing", that is sharing someone's secrets or embarrassing information or sexual images online and "trickery", that is, talking someone into revealing secrets or embarrassing information or (sexual) images online (Willard, 2005, p. 1).

- Taking pictures and videos of someone with the intention of distributing the content to others via mobile phones or online (Hinduja \& Patchin, 2009). Distributing nude images of other learners is not only a form of cyber bullying but also cyber child pornography (Willard, 2011, p. 75).

\section{Schools' responsibility and authority with regard to child pornography}

Schools have the duty to protect, to educate and to discipline with regard to cyber sexual misconduct such as child pornography. If a school requires the learners to use the internet and web services while at school, it also has the responsibility to ensure the learners' personal privacy and data security (Theodore, 2010-11, p. 389). Regardless of the geographic origin of any speech, school officials are responsible for ensuring the delivery of instruction and the wellbeing of all of the learners under their custodial care (Willard, 2011, p. 90). Where the misconduct occurs on the school premises the school will have authority to act through normal disciplinary processes.

However, do schools have the responsibility to discipline a learner who has used his private computer at home to produce or distribute child pornography and do schools have the authority to discipline learners for child pornography which either was not produced or not distributed on school premises? (Shipley, 2011, p. 14; Willard, 2011, p. 76) The following guidelines were deducted from American case law1:

- It depends on whether the learner's posting caused or reasonably likely to cause "substantial disruption" at school or interfere with the rights of other learners to be secure and safe (e.g. create a hostile school environment). This "disruption" could include "violent physical or verbal altercations between students, significant interference with the right of a student to receive an education and feel safe at school, or significant interference with instruction or school operations" (Shipley, 2011, p. 15). Learners' right to freedom of

${ }^{1}$ See Shipley, G. (2011). Cyber misconduct, discipline and the law. Leadership, September/October, 14-16; Thornburgh, D., \& Lin, H. (2004). Youth, pornography, and the Internet. Issues in Science and Technology, Winter, 43-48. 
expression can be limited if such speech is "lewd or otherwise inconsistent to the educational mission of the school" (Willard, 2011, p. 87).

- Schools always have a responsibility to discipline learners who watch, produce or distribute child pornography on the school premises but it must be able to establish a nexus between posting and disruption of school environment if not produced or distributed on the school premises (Shipley, 2011, p. 15; Willard, 2011, pp. $100,109)$. Where the dissemination of images is part of conduct that constitutes bullying or harassment directed at harming a co-learner's reputation or causing a hostile environment at school for that learner, school officials should have the authority to impose discipline for such conduct irrespective of whether it was committed on or of school grounds (Willard, 2011, p. 110).

\section{Observing learners' rights}

Schools should consider learners' right to education, right to freedom of expression and right to privacy when handling instances of cyber child pornography.

The primary purpose of education in terms of the Convention on the Rights of the Child (CRC) is to prepare children for "a responsible adult life" (UN 1989). The CRC Committee Comment no 1, par 9 reads: "Education must also be aimed at ensuring that essential life skills are learnt by every child and that no child leaves school without being equipped to face the challenges that he or she can expect to be confronted with in life." The right to education is an empowering right which enables learners to enjoy their other rights. In light of the importance of technology, part of fulfilling learners' right to education will be to educate them for, what Shipley $(2011$, p. 14) calls, "digital citizenship". Public schools are instrumental for states to fulfil their obligations in terms of the right to education. This reinforces the importance that schools should be places where effective teaching and learning can take place. Victims of child pornography can avoid attending school (Willards, 2011, p. 80) which affects their right to equal education. In Davis v. Monroe County Board of Education 526 U.S. at 652 the court held "... in the context of student-on-student harassment, damages are available only where the behavior is so severe, pervasive, and objectively offensive that it denies its victims the equal access to education".

The European Convention on Human Rights (ETS No. 5) provides that the right to freedom of expression and information as enshrined in Article 10 shall "not prevent States to take measures against offline and online sexual exploitation and sexual abuse of children" (Council of Europe Cybercrime Division, 2012, p. 6). In the South African case De Reuck v DPP 20032 SACR 445 (CC) (at 61) Langa J emphasised that the court endorsed this approach (at 49) and that the criminalisation of the creation, production, importation, distribution and possession of child pornography limits the right to freedom of expression (at 50). Similarly, Alito J in Morse v. Frederic 551 U.S. 393 (2007) (at 424-25) accentuated that learners' right to freedom of speech may be curtailed in the school setting: "But due to the special features of the school environment, school officials must have greater authority to intervene before speech leads to violence". Tinker $v$. Des Moines Independent Community School District 393 U.S. (1969) (at 508-509) the Court acknowledged "the special characteristics of the school environment" by permitting school officials to prohibit student speech if that speech "would substantially interfere with the work of the school or impinge upon the rights of other students, including the right 'to be secure."'

Limiting learners' right to privacy can be justified in certain circumstances such as when the learner's actions threaten the right to education. In such instances the responsibilities of the school outweigh the rights of the individual (Errico, 2000). Ackerman J in Bernstein v Bester 19962 SA 751 (CC) at 65 explanation of the right to privacy is most applicable to learners' right to privacy while at school: "(T)he truism that no right is to be considered absolute implies that from the outset of interpretation each right is always already limited by every other right accruing to another citizen. In the context of privacy this would mean that it is only the inner sanctum of a person, such as his/her family life, sexual preference and home environment, which is shielded from erosion by conflicting rights of the community rights of fellow members placing a corresponding obligation on a citizen, thereby shaping the abstract notion of individualism towards identifying a concrete member of civil society. Privacy is acknowledged in the truly personal realm, but as a person moves into communal relations and activities such as business and social interaction, the scope of personal space shrinks accordingly". The learner's right to privacy is balanced against the school's "ability to efficiently and safely carry out business without undue interference or disruption" (Errico, 2000).

What should further be kept in mind is that when one learner publishes a picture of another learner who sent such picture while in a relationship and with the intention that it should be kept private, the learner making the picture public unjustifiably limits the first learner's right to privacy. In the South African case De Reuck v DPP 20032 SACR 445 (CC) 
(at 61) the court describes the harm done by child pornography as follow: "It strikes at the dignity of children, it is harmful to children who are used in its production, and it is potentially harmful because of the attitude to child sex that it fosters and the use to which it can be put in grooming children to engage in sexual conduct". Langa J further held that: "Moreover, since child pornography is frequently being imported via the Internet and possessed on computers, the ease with which such possessors may become distributors at a touch of a button, as it were, should be taken into account. This exacerbates the risk of harm and further justifies the intrusion of the Act onto the private sphere" (at 90).

\section{Practical ideas}

Schools should consider adopting a strategy that focuses on raising awareness, empowerment, prevention, cooperation and regulation (discipline). Prevention strategies should be developmentally appropriate. Programs for young learners should focus on risky online situations and include practice exercises for refusal and resisting techniques (Dowell et al., 2009, p. 552). Programs for older learners should emphasise learners' acceptance of responsibility for their own protection and their role in promoting the observation of their rights. Older learners should be made aware of the "difference between positive and negative relationships and how pornography may distort their view of what is normal both in terms of body image and sexual relationships" (PSHE Association, 2012). Newman (2009) emphasises the importance of co-operation and the implementation of a school-wide program involving principals, teachers, learners and school counsellors to promote a safe environment.

Hope (2006, p. 320) found that principals and educators tend to be more concerned about the school's image and reputation than the learners. She mentions that educators argue that older learners are accessing pornographic websites from their homes where there are less or no supervision and that what harm could be done was already done when learners arrive at school (Hope, 2006, p. 317). This attitude indicates that victims are totally forgotten. Observing the rights to freedom of expression and privacy of the offenders are important but the rights of the victims should not be forgotten. Schools should provide counselling, as well as emotional and psychological support to the victims.

Delmonico and Griffin (2008, cited in Ownes et al., 2012, p. 100) argue the importance of regulating adolescents' internet access because they "often lack the risk attenuation needed to discern and manage online dangers and content in safe and healthy ways". Learners do not regard the virtual world as real and they do not realise that they will have to take responsibility for their actions in the cyber world just as much as in the real world (Centre for Justice and Crime Prevention, 2011, p. 12). I suggest schools incorporate rules on cyber misconduct in existing schools codes of conduct and adopt school policy on computer and cell phone use. Krent (2012:10) suggests the following steps in dealing with cyber misconduct:

- Separate the medium from the message by determining the underlying misconduct

- Identify where and when the underlying misconduct occurred. That tells you whether it has a "nexus" to the school.

- Investigate thoroughly.

In cases of solicitation or where a learner has sent an image with the expectation that it would remain private, and that image has been disseminated, the learner who coerced and/or distributed it should be disciplined. The question should be which learner is responsible for the disruption at school? The fact that the other learner has been engaged in action that is now causing him or her to be ridiculed does not mean that he or she has caused the substantial disruption (Willard, 2011, p. 111).

\section{References}

Ahn, J., Bivona, L.K., \& DiScala, J. (2011). Social Media Access in K-12 Schools: Intractable Policy Controversies in an Evolving World. Proceedings of the American Society for Information Science and Technology 48, 1-10.

Brett, D. (2009). Bullying privacy and confidentiality: Notes from a seminar given on 16 November 2009. Retrieved from: http://www.blandy.co.uk/furniture/cms/documents/Bullying\%20Privacy\%20and\%20Confidentiality.doc.

Butler, D., Kift, S., \& Cambell, M. (2009). Cyber bullying in schools and the law: Is there an effective means of addressing the power imbalance? eLaw Journal: Murdoch University Electronic Journal of Law 16, 84-114. Retrieved from: http://eprints.qut.edu.au /31602/1/c31602.pdf.

Burton, B. \& Leoschut, L. (2013). Monograph Series, no 12: School Violence in South Africa: Results of the 2012 National School Violence Study. Cape Town: Centre for Justice and Crime Prevention.

Centre for Justice and Crime Prevention. (2011). Cyber bullying and 'sexting' Roundtable report on discussions held at at the Southern Sun Hotel in Newlands, 19th August 2011. Retrieved from: http://cyberbullying.ezipezi.com/downloads/CJCPRoundtable-cyberbullyingreport_19Aug2011.pdf.

Campbell, J. (2008). When 'sex play' becomes dangerous. IOL Lifestyle. Retrieved from: http://www.iol.co.za/lifestyle/when-harmless-sex-play- 
becomes-dangerous-1.624548\#.UdW0yjkaKpo.

Chetty, I. (2009). "Sexting" of revealing images of children is the distribution of child pornography. Retrieved from the ChildlineSA website: http://www.childlinesa.org.za/index.php/issues-affecting-you-teenmenu-11/126-sexting-is-no-joke.

Chetty, I. \& Basson, A. (2006). Report on the internet usage and the exposure of pornography to learners in South African schools. Retrieved through FPB website from: http://www.fpb.org.za/research.

Council of Europe. (2001). Convention on cybercrime, Budapest, 23.XI.2001, European Treaty Series - No. 185. Retrieved from: http://conventions.coe.int/Treaty/en/Treaties/Html/185.htm.

Council of Europe Cybercrime Division. (2012). Provisional Discussion Paper, 4 December 2012. Protecting children against sexual violence: The criminal law benchmarks of the Budapest and Lanzarote Conventions. C. Schulman (Ed.) Retrieved from: http://www.coe.int/t/dghl/cooperation/economiccrime/cybercrime/Documents/ReportsPresentations/2571_Child_benchmark_study_V32_pub_4_Dec12.pdf.

CRC Committee CRC/C/GC/13, Fifty-sixth session, Geneva, 17 January - 4 February 2011

Crofts, T. \& Lee, M. (2013). 'Sexting', Children and child pornography. Sydney Law Review, 35, 85-106.

Duncan, SH. (2010). A Legal Response is Necessary for Self Produced Child Pornography: A Legislator's Checklist for Drafting the Bill. Retrieved from: http://works.bepress.com/susan_kosse/22 http://works.bepress.com/susan_kosse/22.

Dowell, EB., Burgess, AW. \& Cavanaugh, DJ. (2009). Clustering of internet risk behaviors in a middle school student population. Journal of School Health, 79, 547-553.

Errico, P. (2000) Policy issues. Privacy: The individual, institution and the public's right to know Retrieved from: http://www.cepi.vcu.edu /policy_issues/goverance/p_privacy.html.

Film and Publication Board. (South Africa). Reporting child pornography. Retrieved from ProChild website: http://www.fpbprochild.org.za/ReportAbuse.aspx.

Hinduja, S. \& Patchin, JW. (2009). Cyber Bullying Research Center Cyber bullying fact sheet: What you need to know about online aggression. Retrieved from: http://www.cyberbullying.us/cyber bullying_fact_sheet.pdf.

Hope, A. (2006). School Internet use, youth and risk: A social-cultural study of the relation between staff views of online dangers and students' ages in UK schools. British Educational Research Journal 32, 307-329.

Internet Watch Foundation. (2012). Internet Watch Foundation Annual and Charity Report 2012 . Retrieved from: http://www.internetwatch.co.uk/assets/media/annual-reports/FINAL\%20web-friendly\%20IWF\%202012\%20Annual\%20and \%20Charity\%20Report.pdf.

Krent, N. (2012). Disciplining student misconduct in cyberspace. School Administrator 2, 10.

Keyser, M. (2003). The Council of Europe Convention on Cybercrime. Journal of Transnational Law \& Policy, 12, 287-326.

Lenhart, A. (2009). Teens and sexting: How and why minor teens are sending suggestive nude or nearly nude images via text messaging. Retrieved from: http://www.pewinternet.org/ /media//Files/Reports/2009/PIP_Teens_and_Sexting.pdf.

Mukhuthu, Z. (2011). Sex videos shock for SA. Sowetan Live, 13 Decēmber 2011. Retrieved from: http://www.sowetanlive.co.za Inews/2011/12/13/sex-videos-shock-for-sa.

Newman, J. (2009). Cyber bullying and sexting: A new challenge for schools. Willes ED Stop Press, September. Retrieved from: http://www.willis.com/subsites/australia/Documents/Publications/services/Education/Education_Stop_Press_-_Cyber_Bullying_ and_Sexting.pdf.

Owens, EW., Behun, RJ., Manning, JC. \& Reid, RC. (2012). The impact of Internet Pornography on adolescents: A review of research. Sexual addiction \& Compulsivity: The Journal of Treatment \& Prevention 19, 99-122.

PSHE Association. (2012). The role of schools in addressing the impact of pornography and sex in the media. Retrieved from: http://www.psheassociation.org.uk/uploads/media/27/7728.pdf

Reader's Digest. (1998). Illustrated Oxford Dictionary. London: Reader's Digest.

Shipley, G. (2011). Cyber misconduct, discipline and the law. Leadership, September/October, 14-16.

Schrock, A. \& Boyd, D. (2011). Problematic youth interaction online: Solicitation, harassment, and cyberbullying. (Draft version.) In B. Kevin \& L. Webb (Eds.), Computer-Mediated Communication in Personal Relationships (pp. 1 - 53). New York: Peter Lang.

Theodore, S. (2010-11). An integrated response to sexting: utilization of parents and schools in deterrence. Journal of Contemporary Health Law and Policy, xxvii, 365-397.

United Nations Convention on the Rights of the Child, 28 International Legal Materials 1448, 1577 UNTS 3 (20 November 1989).

Wastler, S. (2010). The harm in "sexting"?: Analyzing the constitutionality of child pornography statutes that prohibit the voluntary production, possession, and dissemination of sexually explicit images by teenagers. Harvard Journal of Law \& Gender, 33, 687-702.

Whitear-Nel, N. (2011). Child pornography. e-Mantshi, 66, 8-14. Retrieved from: http://www.justiceforum.co.za/JET/JET-LTN/e-Mantshi issue_66.pdf.

Willard, $\bar{N}$. (2005). Cyberbullying and cyberthreats. Retrieved from: http://marinschools.org/SafeSchools/Documents/BP-CyberBandT .pdf.

Willard, N. (2007). Educator's guide to cyberbullying and cyberthreats. Retrieved from: http://www.cyberbully.org/cyberbully/docs /cbcteducator.pdf

Willard, N. (2011). School response to cyberbullying and sexting: the legal challenges BYU Education and Law Journal, 75-125.

Wortley, R. \& Smallbone, S. (2006). Child Pornography on the Internet: Guide no. 41. Retrieved from: http://www.popcenter.org/problems/child_pornography/print/. 